\title{
STRATEGIES OF EXPRESSING WRITTEN APOLOGIES IN THE ONLINE NEWSPAPERS
}

\author{
Cipto Wardoyo \\ UIN Sunan Gunung Djati Bandung \\ cipto_w@yahoo.com
}

\begin{abstract}
Expressing apology is a universal activity although people have different strategies or ways to express the apology based on the culture, situation, and context. An apology has played a vital role in verbal politeness; it is certainly impolite when someone does not express an apology when he or she has commited an offence to the others. Apologies in the Pragmatic study is classified under speech act theory. An apology based on Searle (1969) is classified as expressive speech acts because it expresses speaker's physiological attitude. An apology expresses speaker's sorrow and regret because he/she has offended hearers or readers. This paper tries to discuss strategies of editors in expressing written apologies in the online newspaper. The objective of this paper is to explain what the strategies of written apologies are in the online newspaper. This study uses qualitative method; the writer chooses descriptive interpretative technique for analyzing data. There are four written apologies in the online nesw papers as data sources in this paper, the data are taken from The Jakarta Post, The Daily Express, The Sun, and Brisbane Times. The writer tries to describe and analyzes utterances in the data sources based on Olshtain \& Cohen theory (1986). There are five main strategies in expressing apologies according to Olshtain \& Cohen (1986); they are Illocutionary Force Indicating Device (IFID), expression responsibility, explanation/justification, offer repairs, and promise forbearance. The writer found that all of the written apologies used combination strategies, they used IFID by using performative verb: apologize and be sorry then followed by expression resposbility, explanation, offer repairs, and promise forbearance.
\end{abstract}

Keywords: apologies, speech acts, politeness, pragmatics

People in their life should communicate to fulfill various needs such as express their ideas or thought for achieving their wants. They as human beings often make mistakes or do some errors. Those problems will offend the other's feeling. People who have done errors and mistakes should make an apology to get recovery of their relationship. In social life, the apology expression is the way to repair relationship that has been broken by misunderstanding or miscommunications.

Expressing apology is a social phenomenon; an apology is a universal activity of expressing regret although people have different strategies or ways to express the apology based on the culture, situation and gender. Expressing apology play a vital role in verbal politeness, it is certainly impolite when someone does not express apology when the context is expected him/her to express an apology. Apology will be happened when speakers believe that the action has offended the hearer.

Saying "I am sorry" without changing behavior is not enough, according to Goffman (1967) expressing apology is the remedial work to put things right. There some consequences 
when someone expressing apology: first believe that the action was wrong, promise will not happen again next time, and offer repair.

Apology has four functions according to Kotani (2002). First, it is the way of wrong doer to express regretful of offence and accept responsibility for it. Second, speakers admit their failure to meet an implicit and explicit obligation. Third, speakers express apology to express sympathy upon hearing of the other misfortune. Apology is also used by speaker to request repetition, reject questions or answers, or announce interruption. Finally, people express apology as a ritualistic remedy to simply fulfill expectation. Apology based on Searle (1969) is classified as expressive because it expresses speaker's physiological attitude. Apology expresses speaker's sorrow and regret because he/she has offended hearers. Expressing apology is very important activity in our life because it can avoid conflict among the people who have problems in their relationship. Moreover, expressing apology is used as a remedy work for repairing mistakes.

Expressing apology can be performed in oral or written form, it depends on the context and the goals of the expressing apology itself. The writer is interested to analyze strategies of expressing written apologies in online newspaper, how the strategies of the editors and the writers expresss their apologies in written form.

This paper tries to discuss strategies of editors in expressing written apologies in the online newspaper. The objective of this paper is to explain what the strategies of written apologies are in the online newspaper. This study uses qualitative method; the writer chooses descriptive interpretative technique for analyzing data. According to Cresswell (1994:2) qualitative is a process of understanding social or human problems in complex building, holistic picture, formed in verbal languages. Similarly, Marvasti (2004:7) states that qualitative research describes and analyzes the quality of human experience. There are four written apologies data in the online neswpapers as data sources in this paper, the data are taken from The Jakarta Post, The Daily Express, The Sun, and Brisbane Times.

\section{Expressing Apology}

Apologies are very familiar utterances in our daily activities; everyone has performed apologies for many reasons. According to Engel (2001:29) there are at least five reasons why expressing apologies to another person become so important. First, expressing apology shows respect to others. Second, apologizing shows that we are able to take responsibility for our actions. Third, apologizing shows that we care the other person's feeling. Next, apologizing shows that we have good integrity. Finally, apologizing shows that we want to make a peace condition and restore relationship with others.

Lazare in Smith (2008:18) offers description of apologies as acknowledgement of an offense and expression of remorse. According to Trosborg (1995) an apology shows expressing regret of the speaker performing bad attitude which hurts other's feeling who fails to do a previous action having negative effects for the hearers. Furthermore, Brown \& Levinson (1992:187) state that apology is negative politeness strategy, motivated by the desire to redress a face threatening acts (FTA): an offence that has impinged on the hearer's freedom of action (negative face) or their need for approval (positive face).

According to Austin (1962) apology is performative utterances because in certain condition, the act of uttering I apologize is means of the act of apologizing. On the other hand, Searle (1976) says that apology belong to the class of expressive which illocutionary point is to express the psychological state.

Apologies according to Fraser (1981) are classified as direct and indirect apology formal and informal. Direct apology for example: I am sorry or I must apologize for, where the verbal statement alone is sufficient. An indirect apology is an apology that is usually accompanied by 
a solution, remedy, promise, or explanation. Olstain \& Cohen (1986) develop Fraser's strategies and propose five strategies in expressing apologies: direct expression of apologies (IFID), an acknowledgement of responsibility, an explanation, an offer repair, and a promise of forbearance.

Direct apology or explicit apology means that apologizer uses a word, an expression, or an utterance which contains a relevant performative verb such as apologize, forgive, excuse, and be sorry. Direct apology is called as Illocutionary Force Indicating Device (IFID).

Second strategy is explanation. Explanation shows an excuse or justification for doing the offence. Explanation of particular situation is indirectly caused the apologizer to commit the offense, and it is usually used by the speaker as indirect speech act of apologizing. It will relate to the context of the offense, the statement is intended to "set things right", for example: in a place where people have bad transportation problems, a person comes late to a meeting and then he gives an explanation by saying:

The bus was very late.

Utterance above as an indirect apology, it is perfectly acceptable reason as an apology because of the context is supported by that condition. The speaker in the example above tries to explain that he comes late to the meeting because there is a problem with the bus, he himself tries to be on time but the bus condition does not support him to be on time in a meeting.

Third strategy is acknowledgement of responsibility. The apologizer recognizes that his or her fault causes the violence. The degree of the violence on the part of apologizer can be placed on scale, the highest level of intensity is an acceptance of the blame, for example:

I know what I did was wrong.

It's my fault.
In the utterances above speaker realizes that he/she has done something wrong then he/ she is responsible with that offence by saying "I was wrong" or "it's my fault". Lower level is an expression of self deficiency: I was confused/ I didn't see/ you are right.

Fourth strategy is offer repair. Sometimes damages may result when someone fails to accomplish his/her commitment as has been promised. Hence, compensation such as repair or payment for damage may be offered as a form of apologies, for example:

\section{I forget to bring your book, I'll bring it tomorrow.}

In the example above, the speaker regrets that he/she forgets to bring his/her friend's book, so as a compensation he/she will bring his/her friend's book at the next day.

Finally, a promise of forbearance, this strategy is the apologizer is expected not to perform the same offence or mistake, and then the apologizer improves their behavior in the future. It is like a promise, for example:

\section{I'm not going to be without a uniform again}

In the examples above, the speaker who as a student realizes that he/she has done something wrong that he/she does not wear school uniforms to school. Hence, he/she promises never to do the offence again.

\section{DISCUSSION}

\section{Data 1}

The first data are taken from www. thejakartapost.com:

We sincerely apologize and retract the editorial cartoon printed on page 7 in the July 3, 2014 edition of The Jakarta Post.

The cartoon contained religious symbolism that may have been offensive to some.

The Post regrets the error in judgment, which was in no way meant to malign or be disrespectful to any religion. 
From the data above, The Jakarta Post expresses its written apology because the editorial cartoon printed on July 3th 2014 contains Islamic symbols which have offended Muslim societies. From the data, it can be seen that The Jakarta Post expresses a direct apology about the editorial cartoon by using expression of Illocutionary Force Indicating Device (IFID) "We sincerely apologize" and then offer a repair by retracting the editorial cartoon which has offended Muslim society. Furthermore, The Jakarta Post expresses acknowledgement of responsibility by using utterances The cartoon contained religious symbolism that may have been offensive to some that utterance expresses The Jakarta Post realizes that the cartoon has offended Muslim society feeling by using religious symbols in the editorial cartoon, then it expresses regret by using utterance The Post regrets the error in judgment. In the last paragraph, The Jakarta Post expresses the explanation strategy by using which was in no way meant to malign or be disrespectful to any religion.

\section{Data 2}

The second data are taken from The Sun online in www.thesun.co.uk:

We would like to apologise for any offence the online headline 'You Schwein' may have caused Bastian Schweinsteiger after the Manchester UnitedBayern Munich match last Tuesday.

It was not our intention to embarrass Bastian or Bayern Munich.

It was removed after one hour and never appeared in any editions of The Sun

The data above tells that The Sun expresses a direct written apology by using explicit utterance "We would like to apologise for any offence the online headline "You Schwein" that utterance The Sun uses performative verb "apologize" as expression of Illocutionary Force Indicating Device (IFID). The Sun in the first utterance also has realized that it has offended Bastian Schweinsteiger after the Manchester United and Bayern Munich match. The next strategy, The
Sun expresses explanation by using utterance It was not our intention to embarrass Bastian or Bayern Munich. Then The Sun expresses offer repair by using utterance It was removed after one hour. Finally, The Sun expresses a promise of forbearance, this strategy is the Sun promises not to perform the same offence by using utterance it never appeared in any editions of The Sun.

\section{Data 3}

The data below are taken from www. brisbanetimes.com.au:

I have become aware that Mike Carlton has corresponded with some Herald readers and letter writers using inappropriate and offensive language.

This behaviour is completely unacceptable.

I have asked Mike to apologise for these actions. Mike regrets his behaviour and will be contacting affected readers to apologise.

On behalf of the Herald, I too apologise for any offence caused.

The data above is the apology written by Darren Goodsir as an editor in the Sydney Morning Herald and The Sun Herald. The data "I have become aware that Mike Carlton has corresponded with some Herald readers and letter writers using inappropriate and offensive language" it shows that Darren realizes that his staff Mike Carlton has offended the Herald readers by using inappropriate and offensive language. The next strategy, Darren uses acknowledgement of responsibility, he recognizes the fault and accepts the blame by using utterance This behaviour is completely unacceptable. After that Darren uses strategy is offer repair by saying Mike regrets his behaviour and will be contacting affected readers to apologise. The last strategy, Darren uses a direct apology about the editorial cartoon by using expression of Illocutionary Force Indicating Device (IFID) I too apologise for any offence caused

\section{Data 4}

The data below are taken from www.express. co.uk

Kate and Gerry McCann: Sorry.

We did so because we accept that a number of 
articles in the newspaper have suggested that the couple caused the death of their missing daughter Madeleine and then covered it up. We acknowledge that there is no evidence whatsoever to support this theory and that Kate and Gerry are completely innocent of any involvement in their daughter's disappearance. We trust that the suspicion that has clouded their lives for many months will soon be lifted. As an expression of its regret, the Daily Express has now paid a very substantial sum into the Madeleine Fund and we promise to do all in our power to help efforts to find her.

Kate and Gerry, we are truly sorry to have added to your distress

From the data above The Daily Express uses a direct strategy using expression of Illocutionary Force Indicating Device (IFID) Kate and Gerry McCann: Sorry. Then the next strategy is explanation, the explanation shows an excuse or justification why the Daily Express writes that Kate and Gerry caused the death of missing daughter by using utterance: we accept that a number of articles in the newspaper have suggested that the couple caused the death of their missing daughter Madeleine.

\section{REFERENCES}

Austin, J.L. (1962). How to Do Things with Words. Great Britain: Oxford University Press.

Blanchard, K. \& Margret, M. (2003). The One Minute Apology. New York: HapperCollins Publishers inc.

Brown, P. \& Stephen, C.L. (1992). Politeness Some Universals In Language Use. Great Britain: Cambridge University Press.

Cohen, A.D, Elite, O. \& David, S.R. (1986). Advanced EFL Apologies: What Remained to be Learned? International Journal Social and Language 62, 51-74.

Cruse, A. (2006). A Glossary of Semantics and Pragmatics. Finland:Edinburgh University Press.
The next strategy The Daily Express uses acknowledgement of responsibility, it acknowledges its mistake by using utterance We acknowledge that there is no evidence whatsoever to support this theory and that Kate and Gerry are completely innocent of any involvement in their daughter's disappearance. The last strategy is offer repair, The Daily Express gives compensation or payment for damage and promises to help Kate and Gerry to find their missing daughter as a form of apologies by using utterance the Daily Express has now paid a very substantial sum into the Madeleine Fund and we promise to do all in our power to help efforts to find her.

The last strategy The Daily Express again expresses a direct apology using Illocutionary Force Indicating Device (IFID) we are truly sorry to have added to your distress

\section{CONCLUSION}

From the data analysis, the writer found that all of written apologies in online newspapers used combination strategies, they used IFID by using performative verb: apologize and be sorry then followed by expression resposbility, explanation, offer repairs, and promise forbearance.

Cutting, J. (2003). Pragmatic and Discourse. New York: Routledge.

Davies, B. (2007). Institutional Apologies in UK higher education: Getting Back into the Black before Going into the Red. Journal Politeness Research, 3.

Engel, B. (2001). The Power of Apology: Healing Step to Transform All Your Relationships. New York: John Willey \& Son, inc.

Grundy, P. (2000). Doing Pragmatic. New York: Oxford University Press

Holtgraves, T. (2008). Language as Social Action: Social Psychology and Language Use. New Jersey: Taylor \& Francis e library

Kadar, D.Z. (2007). On Historical Chinese Apology and its Strategic Application. Journal of Politeness Research 3, 125-150. 
Kampf, Z. \& Shosana, B. (2007). Do Children Apologize to Each Other? Apology Events in Young Israeli Peer Discourse. Journal of Politeness Research, 3, 11-37.

Kasanga, L.A. \& Joy, C. (2007). Cross Cultural Linguistic Realization of Politeness: a Study of Apologies in English and Setswana. Journal of Politeness Research, 3, 65-92.

Leech, G. (1990). Principles of Pragmatics. New York: Longman Group Limited.

Levinson, S.C. (1995). Pragmatics. New York: Cambridge University Press.

Ogiermann, E. (2009). On Apologising in Negative and Positive Politeness Cultures. Amsterdam: John Benjamin Publishing Co.
Ogiermann, E. (2008). On the Culture Specificity of Linguistic Gender Difference: the Case of English and Russian Apologies. Intercultural Pragmatics, 5 (3), 259286.

Smith, N. (2008). I Was Wrong: The Meaning Of Apology. United Kingdom: Cambridge University Press.

Thomas, J. (1995). Meaning in Interaction: An Introduction to Pragmatics. New York: Longman Group limited.

Verschueren, J. (1999). Understanding Pragmatics. London: Oxford University Press.

Yule, G. (1996). Pragmatics. Hongkong: Oxford University Press. 